\title{
NOTE
}

\section{Genetic Relatedness, Among Streptomycetes Producing Tetracycline Antibiotics, Studied by Means of Deoxyribonucleic Acid Association}

\author{
JUNPEI KOIKE, ${ }^{1}$ ICHIRO TAZAWA, ${ }^{2}$ AND TADASHI ARAI \\ Research Institute for Chemobiodynamics, Chiba University, Chiba, Japan
}

\begin{abstract}
The genetic relatedness among streptomycetes capable of producing tetracycline, chlortetracycline, and oxytetracycline was studied by using deoxyribonucleic acid (DNA) association techniques. Reciprocal DNA association experiments yielded genetic similarity values ranging from 75 to $97 \%$ among Streptomyces aureofaciens ATCC 10762, S. aureofaciens ATCC 13911, S. lusitanus CBS $101 \mathrm{~A}$, and $S$. lusitanus var. tetracyclini 106-T ATCC 15843. These four strains should thus be considered members of the same species on the basis of genetic relatedness. On the bases of DNA association experiments, the degree of nucleotide similarity of morphologically heterogeneous strains with $S$. rimosus ATCC10970 was 28 to $33 \%$.
\end{abstract}

The deoxyribonucleic acid (DNA)-DITA association technique has proved to be extremely useful for taxonomic studies. The genetic homology among actinomycetes has been extensively studied by Tewfik and Bradley (9), Monson et al. (5), Farina and Bradley (3), and Bradley (1). A method for the determination of DNA homologies of streptomycetes has been described by Okanishi and Gregory (7), whereas Okanishi et al. (6) evaluated taxonomic criteria in streptomycetes on the basis of DNA homologies. Furthermore, Toyama et al. (10) investigated genetic relatedness of 26 species of whorlforming streptomycetes.

The present note deals with the nucleotide similarity of Streptomyces aureofaciens ATCC 10762 and some related strains, and further among wild-type and variant strains.

The strains listed in Table 1 are capable of producing antibiotics with $\mathrm{Cl}^{-}$present in the medium.

Escherichia coli was used as a control organism. The streptomycetes were cultured with shaking at $27^{\circ} \mathrm{C}$ for $72 \mathrm{~h}$ in a medium consisting of $1.0 \%$ glucose, $0.5 \%$ peptone, $0.5 \%$ meat extract, and $0.5 \% \mathrm{NaCl}$. The final $\mathrm{pH}$ was adjusted before autoclaving to 7.2 to 7.4. E. coli was cultured with shaking at $37^{\circ} \mathrm{C}$ for $48 \mathrm{~h}$ in a medium consisting of $0.5 \%$ peptone, $0.5 \%$ meat extract, and $0.5 \% \mathrm{NaCl}, \mathrm{pH} 7.2$ to 7.4 . For

\footnotetext{
${ }^{1}$ Present address: Faculty of Science, Tokyo Kogyo University, Tokyo, Japan.

${ }^{2}$ Present address: Faculty of Science, Tokyo University, Tokyo, Japan
}

radioactive labeling of DNA, the strains were grown in the minimal medium described by Okanishi and Gregory (7). The DNA samples were prepared by the phenol procedure (8). Such DNA preparations were found to contain less than $2 \%$ ribonucelic acid (RNA) (11) and $8 \%$ protein (4). The specific activity of the labeled DNA preparations was 3,000 to $5,000 \mathrm{cpm}$ per $\mu \mathrm{g}$ as determined by liquid scintillation counting. The DNA-DNA association method was that described by Denhardt (2), carried out on a small scale. About $5 \mu \mathrm{g}$ of unlabeled, denatured DNA was immobilized on a small, membrane filter (Sartorius, $5.5-\mathrm{mm}$ diameter, $0.45-\mu \mathrm{m}$ pore size). The immobilized DNA on the membrane filter (IM-DNA) was preincubated for $6 \mathrm{~h}$ at $75^{\circ} \mathrm{C}$ in $0.2 \mathrm{ml}$ of $6 \times \mathrm{SSC}$ (SSC, $0.15 \mathrm{M} \mathrm{NaCl}$ and $0.015 \mathrm{M}$ sodium citrate, $\mathrm{pH}$ 7.0) and twice-diluted PM as described by Denhardt (2). After the preincubation, the DNADNA association reaction was done for $20 \mathrm{~h}$ at $75^{\circ} \mathrm{C}$ in small test tubes containing the IMDNA and $0.25 \mu \mathrm{g}$ of sheared-denatured DNA (SD-DNA) in $0.2 \mathrm{ml}$ of $6 \times \mathrm{SSC}$ and $0.003 \mathrm{M}$ $\mathrm{MgCl}_{2}$. The SD-DNA was prepared from ${ }^{3} \mathrm{H}-\mathrm{la}$ beled DNA by sonic extraction and Sephadex G-200 gel filtration. For the present study, the adequacy of the association method was established by studies on the effects of temperature, of chain length on the association reaction, and the thermal stability of the associated DNA. The results demonstrated that SD-DNA, having about 300 nucleotide units and incubated at $75^{\circ} \mathrm{C}$, gave the most reliable and reproducible data. 
TABLE 1. Cultures investigated and their origin

\begin{tabular}{|c|c|c|}
\hline Organism & Antibiotic produced & Source $^{a}$ \\
\hline Streptomyces aureofaciens ATCC 10762 & $\begin{array}{l}\text { Chlortetracycline (with chlorine added); tetra- } \\
\text { cycline (without chlorine) }\end{array}$ & Pridham \\
\hline S. aureofaciens ATCC 13911 & Tetracycline (with chlorine added) & ATCC \\
\hline S. lusitanus CBS 101A & $\begin{array}{l}\text { Chlortetracycline (with chlorine added); tetra- } \\
\text { cycline (without chlorine) }\end{array}$ & $\mathrm{ACC}$ \\
\hline $\begin{array}{l}\text { S. lusitanus var. tetracyclini 106-T } \\
\text { ATCC } 15843\end{array}$ & Tetracycline (with chlorine added) & ATCC \\
\hline $\begin{array}{l}\text { S. rimosus ATCC } 10970 \\
\text { Escherichia coli }\end{array}$ & Oxytetracycline & $\begin{array}{l}\text { ATCC } \\
\text { IFM }\end{array}$ \\
\hline
\end{tabular}

${ }^{a}$ Pridham, Thomas G. Pridham, N. Reg. Lab., U. S. Department of Agriculture, Peoria, Ill.; ATCC, American Type Culture Collection, Rockville, Md.; ACC, American Cyanamid Co., New York; IFM, Institute of Food Microbiology, Chiba University, Japan.

TABLE 2. Reciprocal DNA association assays of DNA samples from selected strains of antibiotic-producing streptomycetes and Escherichia coli

\begin{tabular}{|c|c|c|c|c|}
\hline \multirow[b]{2}{*}{ Source of IM-DNA ${ }^{a}$} & \multicolumn{4}{|c|}{ Nucleotide similarity value (\%) } \\
\hline & $\begin{array}{l}\text { Streptomyces aureo- } \\
\text { faciens ATCC } 10762^{b}\end{array}$ & $\begin{array}{l}\text { S. aureofaciens } \\
\text { ATCC } 13911\end{array}$ & $\begin{array}{l}\text { S. lusitanus } \\
\text { CBS 101A }\end{array}$ & $\begin{array}{l}\text { S. lusitanus var. tet- } \\
\text { racyclini } 106-\mathrm{T} \\
\text { ATCC } 15843\end{array}$ \\
\hline $\begin{array}{l}\text { Streptomyces aureofaciens ATCC } \\
\quad 10762\end{array}$ & 100 & 75 & 89 & 77 \\
\hline S. aureofaciens ATCC 13911 & 75 & 100 & 82 & 88 \\
\hline S. lusitanus CBS 101A & 87 & 85 & 100 & 89 \\
\hline $\begin{array}{l}\text { S. lusitanus var. tetracyclini 106- } \\
\text { T ATCC } 15843\end{array}$ & 80 & 80 & 97 & 100 \\
\hline S. rimosus ATCC 10970 & 33 & 30 & 32 & 28 \\
\hline Escherichia coli & 2 & 2 & 1 & 3 \\
\hline
\end{tabular}

${ }^{a}$ IM-DNA, Immobilized DNA on membrane filter.

$b$ Source of reference DNA (sheared-denatured DNA).

Table 2 represents the nucleotide similarity among DNA samples isolated from selected strains of antibiotic-producing streptomycetes. The reciprocal DNA association among morphologically homogeneous strains ( $S$. aureofaciens ATCC 10762, $S$. aureofaciens ATCC 13911, S. lusitanus CBS 101A, and S. lusitanus var. tetracyclini 106-T ATCC 15843) gave from 75 to $97 \%$ nucleotide similarity values. The morphologically different strain, $S$. rimosus ATCC 10970, associated with the above strains from 28 to $33 \%$. These results provide evidence that the former four strains indeed are members of the same species and that $S$. rimosus ATCC 10970 is appreciably different on the basis of genetic relatedness. Nucleotide dissimilarity of $S$. aureofaciens ATCC 10762 and $S$. rimosus ATCC 10970 was reported earlier by Tewfik and Bradley (9).

We thank Y. Sakagami of the Tokyo Kogyo University for helpful suggestions. Part of this work was carried out at the Tokyo Kogyo University.

\section{REPRINT REQUESTS}

Address reprint requests to: Dr. Junpei Koike, 2-14-30503, Miyamoto-Cho, Funabashi, Chiba, Japan.

\section{LITERATURE CITED}

1. Bradley, S. G. 1973. Relationships among mycobacteria and nocardiae based upon deoxyribonucleic acid reassociation. J. Bacteriol. 113:645-651.

2. Denhardt, D. T. 1966. A membrane-filter technique for the detection of complementary DNA. Biochem. Biophys. Res. Commun. 23:641-646.

3. Farina, G., and S. G. Bradley. 1970. Reassociation of deoxyribonucleic acids from Actinoplanes and other actinomycetes. J. Bacteriol. 102:30-35.

4. Lowry, O. H., N. J. Rosebrough, A. L. Farr, and R. J. Randall. 1951. Protein measurement with the Folin phenol reagent. J. Biol. Chem. 198:265-275.

5. Monson, A. M., S. G. Bradley, L. W. Enquist, and G. Cruces. 1969. Genetic homologies among Streptomyces violaceoruber strains. J. Bacteriol. 99:702-706.

6. Okanishi, M., H. Akagawa, and H. Umezawa. 1972. An evaluation of taxonomic criteria in streptomycetes on the basis of deoxyribonucleic acid homology. J. Gen. Microbiol. 72:49-58.

7. Okanishi, M., and K. F. Gregory. 1970. Methods for the determination of deoxyribonucleic acid homologies in Streptomyces. J. Bacteriol. 104:1086-1094.

8. Saito, H., and K. Miura. 1963. Preparation of tranform- 
ing deoxyribonucleic acid by phenol treatment. Biochim. Biophys. Acta 72:619-629.

9. Tewfik, E. M., and S. G. Bradley. 1967. Characterization of deoxyribonucleic acids from streptomycetes and nocardiae. J. Bacteriol. 94:1994-2000.

10. Toyama, H., M. Okanishi, and H. Umezawa. 1974. Het- erogeneity among whorl-forming streptomycetes determined by DNA reassociation. J. Gen. Microbiol. 80:507-514.

11. Webb, J. M. 1956. A sensitive method for the determination of ribonucleic acid in tissues and microorganisms. J. Biol. Chem. 221:635-649.

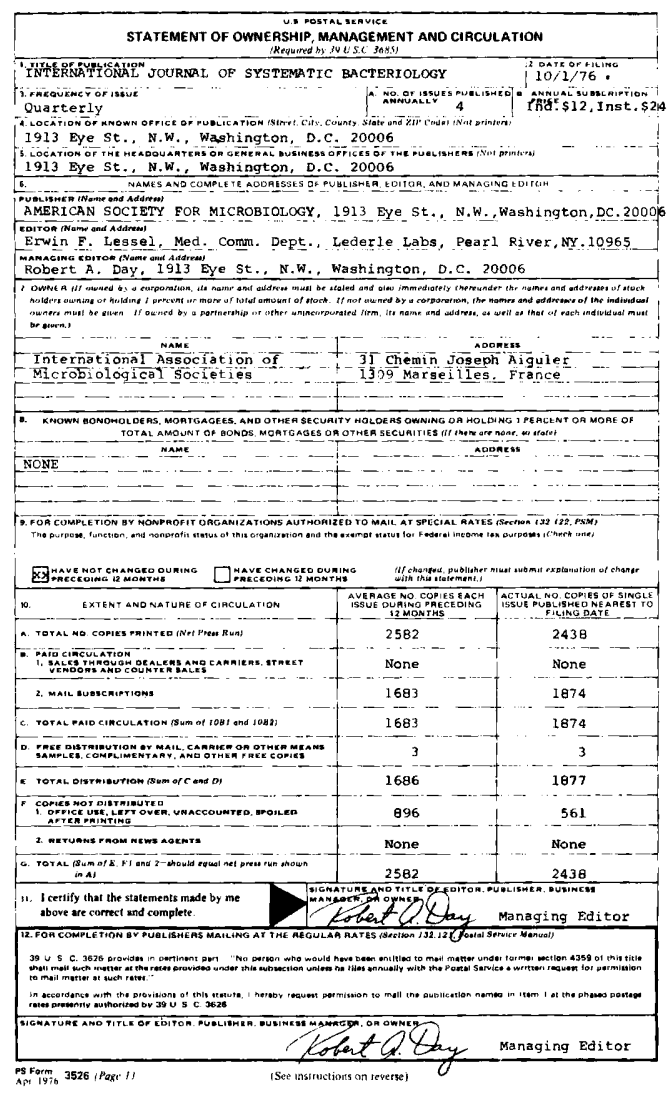

